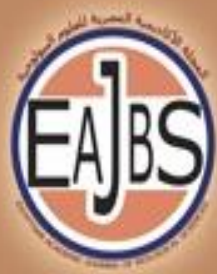

EGYPTIAN ACADEMIC JOURNAL OF
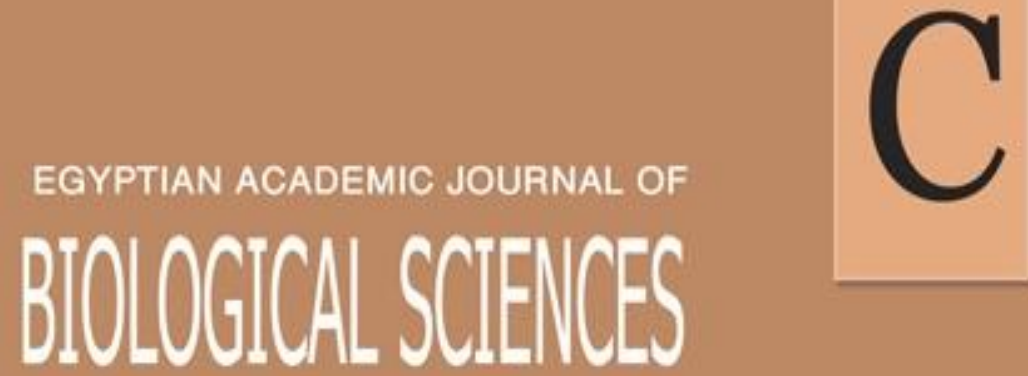

PHYSIOLOGY \& MOLECULARBIOLOGY
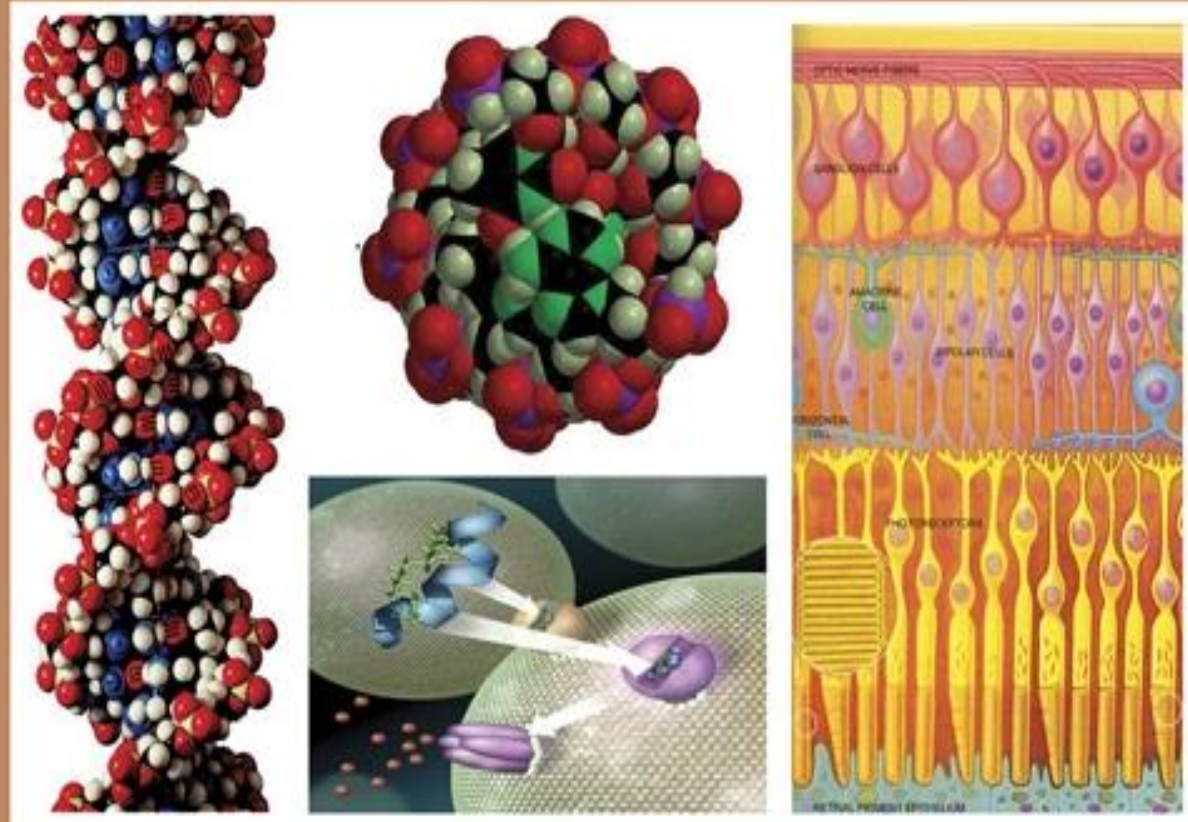

\title{
ISSN
}

2090-0767

Vol. 13 No. 1 (2021) 
Egypt. Acad. J. Biolog. Sci., 13(1):61-70 (2021)

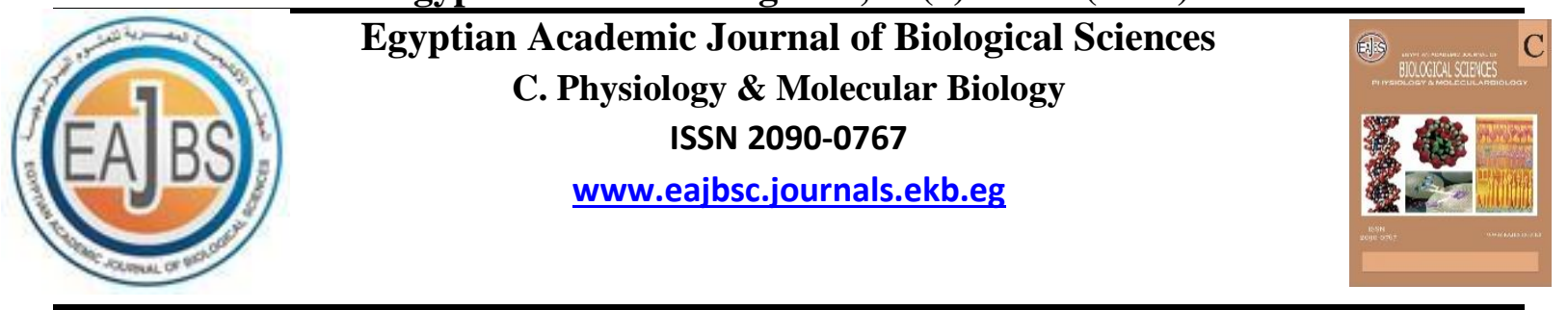

\section{Antioxidant and Antibacterial Activities of Rosmarinus officinalis aqueous extract with Study of The Pharmaco-Toxicological Effect}

\section{Rahmani, S. ${ }^{1}$, Kanoun,K..$^{*}$, and Harir,N. ${ }^{2}$}

1-Biotechnology and Agronomic Sciences Department, Faculty of Natural Sciences and

Life, Hassiba Ben Bouali University of Chlef, Algeria.

2- Laboratory of Molecular Microbiology Health and Proteomics, Biology Department, Faculty of Natural Sciences and Life, Djillali Liabes University of Sidi-Bel-Abbes, BP

$N^{\circ} .89$ Sidi-Bel-Abbes 22000 Algeria.

*E. Mail: khedoudja.kanoun@univ-sba.dz - khedi20022002@yahoo.fr

\section{ARTICLE INFO}

Article History

Received:24/1/2021

Accepted:15/3/2021

Keywords:

Rosmarinus

officinalis,

antioxidant

activity,

antibacterial

activity, anti-

inflammatory

effect, toxicity..

\section{ABSTRACT}

The objective of the present work was to study the antioxidant activit of the aqueous extract and the antibacterial activity of the Rosmarinu officinalis aerial part essential oils. The Rosemary essential oil yield wa equal to $1.47 \%$. A great inhibitory power of Rosemary extract was reveale by the test of antioxidant activity $(93.72 \%)$ by an $\mathrm{IC}_{50}$ of $16.95 \mu \mathrm{g} / \mathrm{ml}$, whic was superior to that of Butylated hydroxy anisol (BHA a syntheti antioxidant) $(6.01 \mu \mathrm{g} / \mathrm{ml})$, and of ascorbic acid $(1.27 \mu \mathrm{g} / \mathrm{ml})$. The essential o antibacterial activity was evaluated against five bacterial strains, using th aromatogram method. Hence, a remarkable antibacterial activity was note for Rosemary essential oil. Gram-positive bacteria were highly sensitive $t$ the activity of this essential oil than the Gram-negativ bacteria. Furthermore, pharmacological investigation of the plant aqueou extract revealed the plant had very important pharmaceutical effects (ant inflammatory effect). The preliminary study of toxicity, according to orc voice, revealed that the Rosmarinus officinalis leaves were not toxic.

\section{INTRODUCTION}

Since antiquity, human beings have used aromatic plants (Bojase et al., 2001). Today, the majority of the world's inhabitants use many plants, either for seasoning or as a remedy in traditional medicine. These plants represent a huge reservoir of potential compounds, attributed to secondary metabolites that possess a wide variety of biological activities (Dorman and Deans, 2000). Rosemary (Rosmarinus officinalis) is the subject of recent research in pharmaceutic, cosmetic and food fields. It's an aromatic herb of the Lamiaceae family, widely used in pharmaceuticals and traditional medicine and appreciated for its antimicrobial, antispasmodic, emmenagogues and anti-tumor properties, (Ait Bekkara et al., 2007). Recent researches have focused on the study of the antioxidant, and antimicrobial molecules of polyphenols and essential oils of this herb. In the present work, we have objectified the study of antioxidant and antimicrobial activity of Rosmarinus officinalis, harvested from the region of Chlef (North- West of Algeria), as well as, determination of the anti-inflammatory activity of its aqueous extract. 


\section{MATERIALS AND METHODS}

Our study was focused on a plant species, Rosmarinus officinalis of the Lamiaceae family. Its aerial part was harvested in February 2019, in the Kremia region of Chlef town (NorthWest of Algeria), far from any pollution impact. To get rid of dust and other particles, the plant aerial parts were washed with running water and dried in the shade in a dry and ventilated place for 7 days. Before any extraction, the plant leaves were dried in the oven for 72 hours at $+40 \mathrm{C}$ to complete the drying.

The bacterial species that were tested for antibacterial activity with Rosmarinus officinalis essential oil included: two strains from the international collection ATCC (American Type Culture Collection): Pseudomonas aeruginosa ATCC 25763 and Staphylococcus aureus ATCC 25843, and three isolated strains from patients from Chlef Hospital (H): (Escherichia. coli $(\mathrm{H})$, Bacillus $s p(\mathrm{H})$ and Streptococcus $s p$ (H)).

The used animal material was Albinos mice strains from Naval Medical Research Institute of Swiss origin; male sex, weight was at 18 to $25 \mathrm{~g}$, the animals were divided into 3 lots of 5 mice. All experimental protocols were conducted on mice in accordance with the standards established by the International Committee of Animals Ethics, consistent with those agreed upon by the European Community on 24 November 1986 (86/609/EEC).

\section{Rosmarinus officinalis Extraction:}

The fresh aerial parts (20-200 g) of leaves, flowers, branches and flowering plants were chopped into small parts, with a blender and placed in a 3-litre roundbottom flask with $1 \mathrm{~L}$ of deionized water. The solution was steam-distilled for $1 \mathrm{~h}$ in a Clevenger type apparatus to oil isolation.The residue was extracted using methanol and acetone by a Soxhlet. The essential oil was stored at $+4^{\circ} \mathrm{C}$ until be used. The yield calculation was defined as the relationship between the mass of the essential oil obtained and the mass of plant matter to be treated (Belyagoubi, 2006).

- $\mathrm{R}-\mathrm{MH} / \mathrm{MS} .100$

- R: Fixed extract yield in g/100g

- MHE: The extract amount recovered in $\mathrm{g}$

- MS: The plant material amount used for extraction, expressed in $\mathrm{g}$.

\section{Antioxidant Activity:}

The antioxidant activity test has been used (Annie et al., 2006). DPPH was solubilized in methanol to $0.1 \mathrm{M} .1 \mathrm{ml}$ of this solution was added to $1 \mathrm{ml}$ of the extract solution $(1 \mathrm{mg} / \mathrm{ml})$ in distilled water, at different concentrations $(05 ; 10$; 20; 40 and $60 \mathrm{~g} / \mathrm{ml}$ ). After $30 \mathrm{~min}$ in the dark and at room temperature, the absorbance was measured at $517 \mathrm{~nm}$, and the test was repeated 3 times. The same protocol was performed for positive control, by a standard antioxidant solution of ascorbic acid and BHA. The results were expressed in inhibition percentages according to the following formula: \% scavenging radical DPPH $=(\mathrm{CA}-\mathrm{SA} / \mathrm{CA})$ $\mathrm{x}$ 100, Where: CA: Control absorption (DPPH-methanol); SA: Sample Absorption [Sample Absorption (SampleDPPH) - Control test Absorption (Sample-methanol).\% scavenging radical $\mathrm{DPPH}=(\mathrm{CA}-\mathrm{SA} / \mathrm{CA}) \times 100$, Where: CA: Control absorption (DPPH-methanol); SA: Sample Absorption [Sample Absorption (Sample-DPPH) - Control test Absorption (Sample-methanol).

\section{Antibacterial Activity:}

The purity of strains control has been assured by re-isolation of each used strains on the specific isolation medium. The strain transplanting was done from the growth medium, incubated at $37^{\circ} \mathrm{C}$ for 24 hours. The antibacterial activity evaluation was carried out by the discs diffusion method or aromatogram. The disc distribution applied method was described by (Gachkar et al., 2007 and 
Hussain et al., 2010).

Rosemary essential oil was dissolved in methyl sulfoxide (DMSO) to prepare different concentrations of successive dilutions at half. DMSO is the solvent wich was used by the majority of searchers, notably, (Gachkar al., 2007), who showed that DMSO has no antibacterial effect. To obtain a young bacterial culture and isolated colonies, used bacteria were seeded on Petri dishes containing nutrient agar (NA), and incubated at $37 \mathrm{C}^{\circ}$ for 24 hours. From these dishes, a few well-isolated and perfectly identical colonies are scraped with a platinum handle. In the case of Streptococcus sp., a swab was used to remove more easily bacterial colonies. Then the handle or swab was resuspended in 5 to $10 \mathrm{ml}$ of physiological water $(0.9 \%)$. In the case of Streptococcus sp., bacterial suspension was well homogenized. Its opacity must be equivalent to 0.5 (Mc Farland) or a D.O from 0.08 to 0.10 , was read at $625 \mathrm{~nm}$. The antibacterial activity of the Rosemary extracts was estimated qualitatively, by using the disk diffusion technique. The agar medium surface was inoculated with initial culture adjusted to $10^{6}$ colony forming units (CFU) /ml. Filter paper disks (6 $\mathrm{mm}$ in diameter; Whatman paper No. 1, USA), were impregnated with 40 $\mathrm{ml}$ of extracts (concentration 6-18 $\mathrm{mg} / \mathrm{ml}$ ). The disks were dried at room temperature. Petri dishes were then incubated at $37^{\circ} \mathrm{C}$ for $24 \mathrm{~h}$. The antibacterial activity was determined through the zone of bacterial growth inhibition around the disk. Controls were set up with solvents alone in corresponding amounts to the highest amount quantity present in the test.

\section{The Aqueous Extract:}

The extraction method used was the infusion which consist to pouring boiled water on the plant material for a necessary time. This time varied on the plant nature from 10 minutes to 1 hour.
This so, $1 \mathrm{~g}$ of plant powder was mixed with $10 \mathrm{ml}$ of boiling distilled water. The solution was left infused for 20 minutes and then filtered.

\section{Toxicity Study:}

This test includes abnormal toxicity according to the European Pharmacopeia, 2005. The purpose of this test is to define the toxicity of the used plant (Rosemary), regardless of the used dose. It's about the toxicological study, by testing the maximum concentration of our infusions; which can lead to mortality. We used 3 batches of 5 samesex mice, with a weight varying from 18 $\mathrm{g}$ to $25 \mathrm{~g}$. We tried different doses of Rosemary leaves aqueous extract. The used doses were increasing dilutions up to the value that gives mortality. The administration was carried out by gavage, at a rate of $0.5 \mathrm{ml} /$ mouse. The observation time lasted over 48 hours.

\section{Anti-inflammatory Test:}

The reveal of anti-inflammatory activity was performed by using the Levy method (Levy, 1969), cited by (Berkan et al., 1991). The general principle is to reduce experimentally in animals, an inflammatory process that will be antagonized by substances; which possess an anti-inflammatory activity, administered before the plant aqueous extract. This technique was performed on homogeneous mice subjected to fasting for 18 hours. This test consists to evaluating the aqueous extract antiinflammatory effect at $10 \%$ and $16 \%$ on the edema of the hind legs, caused by the injection of $1 \%$ of carraghenin solution in mice. Injecting this solution under plantar aponeurosis of the mouse leg causes an inflammatory reaction that can be reduced by an anti-inflammatory product. The carraghenin solution preparation was made by a $20 \mathrm{mg}$ latter dilution in $20 \mathrm{ml}$ of physiological water. The aqueous extract preparation was carried out by infusion at the rate of $1 \mathrm{~g} / 10 \mathrm{ml}$ and $1.6 / 10$ $\mathrm{ml}$ of Rosemary powder. The animals 
were divided into 3 batches.

- Lot control: each mouse received

$0.5 \mathrm{ml}$ of physiological water

- Lot test 1: Each mouse received 0.5 of $10 \%$ of infusion.

- Lot test 2: Each mouse received $0.5 \mathrm{ml}$ of $16 \%$ of infusion.

After 1 hour, the carraghenin solution (1\%) was injected under plantar aponeurosis of the right hind legs, at a volume of $0.025 \mathrm{ml}$ to all mice of the different experimentation batches.

These same mice received an injection of $0.025 \mathrm{ml}$ of physiological water into the left hind legs.

The volume of the right and left hind legs of the 3 lots was measured after 30 minutes using a calliper. The percentage of edema reduction was calculated using the following formula: $\%$ Edema reduction $=\%$ of edema control $-\%$ of edema test / \% of edema control (Berkan et al., 1991).

\section{RESULTS}

The Rosmarinus officinalis essential oil obtained by hydrodistilation was a viscous liquid, clear with a yellowish coloration and a strong smell characteristic of Rosemary. The essential oil yield of local Rosmarinus officinalis was $1.47 \%$.

\section{Antioxidant Activity:}

The results were expressed as an antiradical activity percentage, according to the concentration of standards BHA and ascorbic acid; for the extract, it's also expressed, by using the $\mathrm{IC}_{50}$ parameter, which is defined as the substrate concentration that causes a 50\% DPPH activity loss. The results of anti-radical activity, towards the radical DPPH, standard and extract are represented in (Figure.1) .

The results of the DPPH test showed that Rosemary extract has an inhibition percentage equal to $93.72 \%$ with an $\mathrm{IC}_{50}$ of $16.95 \mu \mathrm{g} / \mathrm{ml}$, which is higher than that of BHA $(6.01 \mu \mathrm{g} / \mathrm{ml})$ and ascorbic acid $(1.27 \mu \mathrm{g} / \mathrm{ml})$.

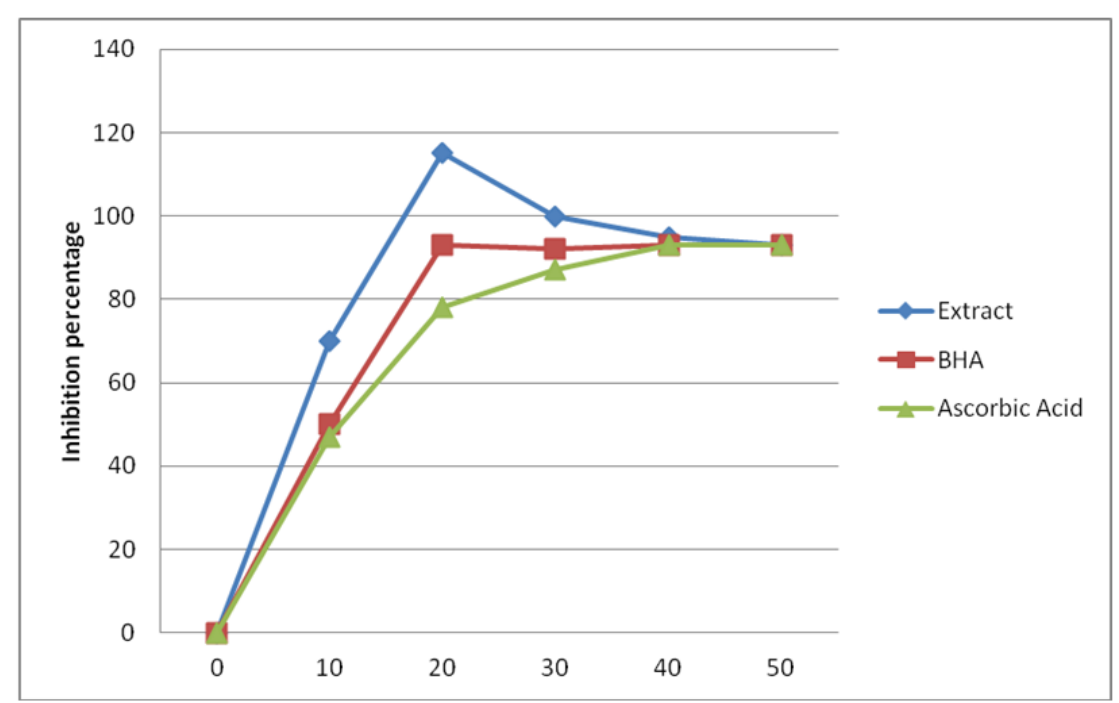

Fig. 1: Inhibition percentage of radical DPPH based on the extract concentration, BHA and ascorbic acid

\section{Evaluation of Antibacterial Activity:}

The antimicrobial power of this essential oil was obtained by calculating diameters of inhibition zones diameters in $\mathrm{mm}$. The results presented in ( Table.1), show that Rosemary's essential oil had an important activity, extending over all the tested strains; but it exerted a strong activity on gram-positive bacteria. Moreover, our results showed that the antibacterial activity, of Rosmarinus officinalis essential oils, increased 
considerably with the extract concentration. According to the classification of (Ponce et al., 2003), inhibition zones, ranging from 15 to 19 $\mathrm{mm}$, indicate that the Bacillus sp. strain was the most sensitive than the other tested strains (inhibition zone between 7 $14 \mathrm{~mm})$. The antibacterial effect of Rosemary essential oil persisted until dilution 1/16 for Escherichia coli $(\mathrm{H})$, Streptococcus sp. $(\mathrm{H})$, and Pseudomonas aeruginosa ATCC 25763.

\section{Abnormal Toxicity Study:}

Even used doses of Rosemary aqueous extract administration (over 48 hours) in the abnormal toxicity test were very high; we didn't notice mice mortality in our experiments (Table .2).

Table 1: Inhibition zones diameters of Rosemary essential oils on the different tested bacterial strains.

\begin{tabular}{|c|c|c|c|c|c|c|}
\hline $\begin{array}{c}\text { Inhibition zones } \\
\text { diameters (mm) }\end{array}$ & \multicolumn{7}{|c|}{ Dilution of Rosemarv essential oils } \\
\cline { 2 - 7 } Strains & $1 / 2$ & $1 / 4$ & $1 / 8$ & $1 / 16$ & $1 / 32$ & NG \\
\hline Escherichia coli & $10.29 \pm 0.565$ & $10.27 \pm 1.620$ & $10 \pm 1.515$ & $8 \pm 1.613$ & $7 \pm 1.513$ & $\mathbf{6}$ \\
\hline Bacillus sp. & $14 \pm 1.2$ & $13.41 \pm 0.419$ & $6 \pm 0$ & $6 \pm 0$ & $6 \pm 0$ & $\mathbf{6}$ \\
\hline $\begin{array}{c}\text { Staphylococcus } \\
\text { aureus }\end{array}$ & $12.52 \pm 0.611$ & $11.21 \pm 0.591$ & $7 \pm 0$ & $6 \pm 0$ & $6 \pm 0$ & $\mathbf{6}$ \\
\hline Streptococcus sp. & $13.5 \pm 0.611$ & $11.05 \pm 0.519$ & $9.01 \pm 2.304$ & $8 \pm 1.307$ & $7.51 \pm 1.161$ & $\mathbf{6}$ \\
\hline $\begin{array}{c}\text { Pseudomonas } \\
\text { aeruginosa } \\
\text { ATCC 25763 }\end{array}$ & $12.34 \pm 1$ & $12 \pm 0$ & $11.1 \pm 1$ & $9 \pm 1.370$ & $7 \pm 1$ & $\mathbf{6}$ \\
\hline
\end{tabular}

NG: negative control (DMSO); (1/2, 1/4, 1/8, 1/16, 1/32): different Rosemary essential oil dilutions.

Table 2: Results of the Rosemary aqueous extract administration

\begin{tabular}{|c|c|c|c|}
\hline Doses (g/ml) & $\mathbf{5} \mathbf{g} / \mathbf{2 0} \mathbf{m l}$ & $\mathbf{1 0} \mathbf{g} / \mathbf{2 0} \mathbf{m l}$ & $\mathbf{1 5} \mathbf{g} / \mathbf{2 0} \mathbf{m l}$ \\
\hline Mice number & 10 & 10 & 10 \\
\hline Dead mice number & 0 & 0 & 0 \\
\hline
\end{tabular}

\section{Anti-Inflammatory Effect of Rosemary Aqueous Extract:}

The results of physiological water and plant aqueous extracts administration to mice, in which inflammation was caused by the injection of carraghenin $(1 \%)$ into the plantar surface of the hind legs, and the thickness estimations of the hind legs (in $\mathrm{mm}$ ) were mentioned in ( Table.3)

After the carraghenin administration at the mice hind legs, the edema formation and the thickness increase of the hind legs were observed in mice in the 3 replicats. After 30 minutes of the carraghenin administration, there was a slight edema decrease in the control lot. The reduction of these edemas was very slow over time; they don't reach the stabilization point until after 201 minutes of the injection. For mice in lot 1 test, with a dose of $1 \mathrm{~g} / \mathrm{ml}$ of the administered extract; there was a significant drop in edema after 30 minutes. The stabilization time was 180 minutes from the injection. For mice in lot 2 test with a dose of 1.6 $\mathrm{g} / \mathrm{ml}$, a very significant drop in edema was observed and the edema reduction was very rapid. They reach stabilization after 120 minutes of injection (Tables .3 and Table .4). 
Table 3: Evolution of the thickness average of the mice right legs in each batch

\begin{tabular}{|c|c|c|c|c|c|c|c|c|c|c|}
\hline & $\begin{array}{l}\text { Before } \\
\text { Admin }\end{array}$ & $\begin{array}{c}\text { After } \\
\text { Admin }\end{array}$ & $\begin{array}{l}\text { After } \\
30 \\
\mathrm{mn}\end{array}$ & $\begin{array}{l}\text { After } \\
60 \\
\mathrm{mn}\end{array}$ & $\begin{array}{l}\text { After } \\
90 \\
\mathrm{mn}\end{array}$ & $\begin{array}{l}\text { After } \\
120 \\
\mathrm{mn}\end{array}$ & $\begin{array}{l}\text { After } \\
150 \\
\mathrm{mn}\end{array}$ & $\begin{array}{l}\text { After } \\
180 \\
\mathrm{mn}\end{array}$ & $\begin{array}{l}\text { After } \\
210 \\
\mathrm{mn}\end{array}$ & $\begin{array}{l}\text { After } \\
240 \\
\mathrm{mn}\end{array}$ \\
\hline $\begin{array}{c}\text { Control: } \\
\text { Physiological } \\
\text { water - } \\
\text { carraghenin } \\
\end{array}$ & $\begin{array}{c}2.25 \pm \\
0.05\end{array}$ & $\begin{array}{r}3.27 \pm \\
0.18\end{array}$ & $\begin{array}{c}3.52 \pm \\
0.08\end{array}$ & $\begin{array}{c}2.92 \pm \\
0.12\end{array}$ & $\begin{array}{c}2.71 \pm \\
0.18\end{array}$ & $\frac{2063}{0.13}$ & $\begin{array}{c}2.51 \pm \\
0.14\end{array}$ & $\begin{array}{c}2.42 \pm \\
0.13\end{array}$ & $\begin{array}{c}2.34 \pm \\
0.05\end{array}$ & $\begin{array}{c}2.34 \pm \\
0.05\end{array}$ \\
\hline $\begin{array}{l}\text { Test 1: aqueous } \\
\text { extract at } 10 \%+ \\
\text { carraghenin }\end{array}$ & $\begin{array}{c}2.41 \pm \\
0.02\end{array}$ & $\begin{array}{c}3.36 \pm \\
0.01\end{array}$ & $\begin{array}{c}2.97 \pm \\
0.15\end{array}$ & $\begin{array}{c}2.78 \pm \\
0.01\end{array}$ & $\begin{array}{c}2.65 \pm \\
0.15\end{array}$ & $\begin{array}{c}2.58 \pm \\
0.11\end{array}$ & $\begin{array}{c}2.49 \pm \\
0.10\end{array}$ & $\begin{array}{c}2.38 \pm \\
0.15\end{array}$ & $\begin{array}{c}2.41 \pm \\
0.03\end{array}$ & $\begin{array}{c}2.41 \pm \\
0.03\end{array}$ \\
\hline $\begin{array}{l}\text { Test 2: aqueous } \\
\text { extract at } 16 \%+ \\
\text { carraghénin }\end{array}$ & $\begin{array}{c}2.32 \pm \\
0.01\end{array}$ & $\begin{array}{c}3.15 \pm \\
0.12 \\
\end{array}$ & $\begin{array}{c}2.63 \pm \\
0.07 \\
\end{array}$ & $\begin{array}{c}2.43 \pm \\
0.14 \\
\end{array}$ & $\begin{array}{c}2.32 \pm \\
0.15 \\
\end{array}$ & $\begin{array}{c}2.27 \pm \\
0.13 \\
\end{array}$ & $\begin{array}{c}2.27 \pm \\
0.13 \\
\end{array}$ & $\begin{array}{c}2.27 \pm \\
0.13 \\
\end{array}$ & $\begin{array}{c}2.27 \pm \\
0.13 \\
\end{array}$ & $\begin{array}{c}2.27 \pm \\
0.13 \\
\end{array}$ \\
\hline
\end{tabular}

Admin : Administration

Table 4: Reduction percentage in edema straight hind leg mice.

\begin{tabular}{|c|c|c|c|c|c|c|c|c|}
\hline & $\begin{array}{c}\text { After } \\
\mathbf{3 0} \mathbf{~ m n}\end{array}$ & $\begin{array}{c}\text { After } \\
\mathbf{6 0} \mathbf{~ m n}\end{array}$ & $\begin{array}{c}\text { After } \\
\mathbf{9 0} \mathbf{~ m n}\end{array}$ & $\begin{array}{c}\text { After } \\
\mathbf{1 2 0} \mathbf{~ m n}\end{array}$ & $\begin{array}{c}\text { After } \\
\mathbf{1 5 0} \mathbf{~ m n}\end{array}$ & $\begin{array}{c}\text { After } \\
\mathbf{1 8 0} \mathbf{~ m n}\end{array}$ & $\begin{array}{c}\text { After } \\
\mathbf{2 1 0} \mathbf{~ m n}\end{array}$ & $\begin{array}{c}\text { After } \\
\mathbf{2 4 0} \mathbf{~ m n}\end{array}$ \\
\hline $\begin{array}{c}\text { Reduction \% of } \\
\text { leg edema in } \\
\text { the control lot }\end{array}$ & $5.6 \%$ & $6.88 \%$ & $7.52 \%$ & $5.41 \%$ & $4.97 \%$ & $4.74 \%$ & $4.17 \%$ & - \\
\hline $\begin{array}{c}\text { Reduction \% of } \\
\text { leg edema in } \\
\text { the control lot } \\
\text { Test : 1 }\end{array}$ & $13.71 \%$ & $7.11 \%$ & $6.78 \%$ & $4.81 \%$ & $3.82 \%$ & $0.91 \%$ & - & - \\
\hline $\begin{array}{c}\text { \% of reduction } \\
\text { of leg edema in } \\
\text { the control lot } \\
\text { Test: 2 }\end{array}$ & $16.01 \%$ & $8.21 \%$ & $4.21 \%$ & $0.98 \%$ & - & - & - & - \\
\hline
\end{tabular}

\section{-: : Stabilization of the edema reduction}

\section{DISCUSSION}

This work was conducted to describe the antioxidant performance and effectiveness of Rosmarinus officinalis essential oils. The essential oil yield of our Rosmarinus officinalis was $1.47 \%$. This yield was close to that cited by Karimi et al. (2006) at $1.5 \%$ and Hilan et al. (2006) at $1.52 \%$, and lower than that cited by Hosny et al. (2011) at $1.79 \%$ and Ayadi (2011) at $85 \%$. However, it was higher than that cited by Atik Bekkara et al. (2007) at $0.8 \%$ and Glick et al. (2007) at $1.18 \%$. This differt depending on geographical location of Rosmarinus officinalis or used extracting method.
Our results showed a high radical scavenging activity using DPPH method. Indeed, the DPPH test results showed that Rosemary extract had an inhibition percentage equal to $93.72 \%$ with an $\mathrm{IC}_{50}$ $16.96 \mu \mathrm{g} / \mathrm{ml}$, which was higher than that of BHA $(6.01 \mu \mathrm{g} / \mathrm{ml})$ and ascorbic acid $(1.27 \mu \mathrm{g} / \mathrm{ml})$. These obtained values were higher than that reported by Athamena et al. (2015) in Constantine (East of Algeria), which was in the order of $80.50 \%$. The $\mathrm{IC}_{50}$ value was $16.96 \mu \mathrm{g} / \mathrm{ml}$ that obtained for the Rosmarinus officinalis aqueous extract exhibits a high antioxidant activity compared to the $\mathrm{IC}_{50}$ $(0.023 \mathrm{mg} / \mathrm{ml})$ and $(54 \mu \mathrm{g} / \mathrm{ml})$ values; 
obtained for the same species reported by Dorman et al. (2003) and Erkan et al. (2008) respectively. This may be due to several factors such as extraction method, the phenolic compounds nature in the extracts, the total phenolic compound content, the geographic localization and the plant's collection period (Stefanovits et al., 2003).

Our extracts showed effective antibacterial activity of Rosemary essential oils fractions against all tested bacterial strains. According to $\mathrm{Wu}$ et al. (2005), the resistance results could be due to the outer membrane chemical composition of Gram-negative bacteria. In fact, they have a membrane that had selective permeability, the lipopolysacharides surface, contains negative charges that prevent the spread of hydrophobic molecules and porins that block the passage of molecules with a high molecular weight. The results of Ayadi et al. (2011) revealed that the clinical Pseudomonas aeruginosa strain was resistant with a diameter of $07 \mathrm{~mm}$ and Pseudomonas aeruginosa ATCC 25763 was sensitive with an inhibition zone of $09 \mathrm{~mm}$. Moreover, the disk charge influences antimicrobial activity. Rasooli et al. (2008) have noticed that the Aspergillus parasiticus growth inhibition was higher when the disc was more charged with Rosmarinus officinalis essential oils. Some studies didn't show any selective antibacterial activity against bacteria's Gram (Gram + or Gram-) (Guesmi and Boudabous, 2006). The Streptococcus sp. strain resistance can be attributed to the antibacterial molecules ability to spread evenly on the agar (Hayouni et al., 2007). All our data suggested that the antibacterial Rosemary extracts efficacy was associated with their specific phenolic composition.

Considering a huge number of different groups of chemical compounds present in Rosemary essential oils, it's most likely that their antibacterial activity is not attributable to one specific mechanism, but that there are several targets in the cell. An important characteristic of essential oils and their components is their hydrophobicity, which enables them to partition in the lipids of the bacterial cell membrane, disturbing the structures and rendering them more permeable. Ions leakage and other cell contents can then occur and causes the death of bacterial cells. Generally, the essential oils possessing the strongest antibacterial properties against food pathogens, contain a high percentage of phenolic compounds, such as carvacrol, eugenol and thymol. The mechanisms of the essential oils action include the cell wall degradation, the cytoplasmic membrane damaging, increased permeability leading to leakage of the cell contents, reducing the proton motive force, reducing the intracellular ATP (Adenosine Three Phosphate) pool via decreased ATP synthesis and augmented hydrolysis; that is separate from the increased membrane permeability and reducing the membrane potential via increased membrane permeability (Hayouni et al., 2007).

The increased public sensibilities of the negative effects caused by overexposure to synthetic chemicals led to the search for "green solutions", such as organic and synthetic free-chemical food products. Rosemary is an available herb, inexpensive, and was shown to be relatively non-toxic in animal models and as antimutagenic. Our in vivo bioassays results showed that Rosemary aqueous extract contained a higher activity than previously described based on the obtained results, it's inferred that the Rosemary aqueous extract has an antiinflammatory effect. Several studies have been conducted on the anti-inflammatory activity evolution of plant aqueous extracts using other methods. Dongmo et al.(2008) showed that the Citrus scinensis aqueous extract had a remarkable anti- 
inflammatory effect. Our results are consistent with Cheung and Tai, (2007) who highlighted the anti-inflammatory effect of Rosemary leaves aqueous extract. The anti-inflammatory activity of the Rosmarinus officinalis aqueous extract can be explained by its richness in phenolic compounds, especially flavonoides. Indeed, Flavonoides inhibit inflammation by decreasing the release of certain mediators (Manunta et al., 2004). Their pharmacological effectiveness as anti-inflammatory compounds depends on their basic structure of hydroxyl residues. They exert a suppressive effect on mediators at the level of inflamed tissues (TakanoIshikawa et al., 2006).

\section{CONCLUSION}

Rosmarinus officinalis exhibited an effectiveness antioxidant, antibacterial and anti-inflammatory activity and was relatively non-toxic in animal models. More studies are essentially needed to highlight the different biologically active compounds of this available and inexpensive herb; which are related to its potential effects.

\section{Conflicts of Interest}

The authors declare that they have no conflicts of interest with respect to the publication of this document.

\section{REFERENCES}

Annie, S .;Arun ,S.; Kuppusamy ,R. and Isaac ,S .R. P. (2006) In vitro antioxidant studies on the benzyl tetra isoquinoline alkaloid berberine .Biological and Pharmceutical Bulletin, 29(9):1906-1910.

Ardestani, A. and Yazdanparast, R.; (2007) Antioxidant and free radical scavenging potential of Achillea santolina extracts. Food Chemistry, .104(1): 21-29.

Athamena, S.; Chalghem, I.;. KassahLaouar , A .; Laroui ,S. and Khebri , S. (2010) Activité antioxydante et antimicrobienne d'extraits de Cuminum cyminum $\mathrm{L}$.
Lebanese Science Journal, 11(1):69-81.

Atik Bekkara, F.; Bousmaha, L. ; Taleb Bendiab S.A .;Boti , J.B. and Casanova ,J .(2007) Composition chimique de l'huile essentielle de Rosmarinus officinalis .L poussant à l'état spontané et cultivé de la région de Tlemcen. Biologie \& Santé, 7 (1) :6-11.

Ayadi, S.; Jerribi , C. and Abderrabba , M. (2011) Extraction et étude des huiles essentielles de Rosmarinus officinalis cueillie dans trois régions différentes de la Tunisie. Journal de la Société Algérienne de Chimie, 21(1) : 25-33.

Belyagoubi L. (2006) Effet de quelques essences végétales sur la croissance des moisissures de détérioration des céréales. Mémoire de Magister. Université Abou Bekr Belkaid, p.110.

Berkan, T.; Ustünes, L.; Lermioglu , F. and Ozer , A. (1991) Antiinflammatory analgesic and antipyretic effects of an aquous extracts of Erythraea centaurium. Planta Medica, 57(1):34-37.

Bojase ,G.; Wanjala ,C. C. and Majinda R.R. (2001) Flavonoids from the stem bark of Bolusanthus speciosus. Phytochemistry,56(8): 837-841.

Cheung, S. and Tai, J. (2007) Antiproliferative and antioxidant properties of rosemary Rosmarinus officinalis. Oncology Reports, 17(6):1525-1531.

Dongmo ， P.M. J .;Tchoumbougnang ,F.; Tchinda ,S .E .; Manedong, S. K.; Amvam Zollo , P.H .and Menut ,C . (2008) Antioxidant and anti-inflammatory potential of essential oils of some Zanthoxylum (Rutaceae) of Cameroon .International journal of essential oil therapeutics, 2 (2):82-88.

Dorman , H .J. and Deans,S .G .(2000) 
Antimicrobial agents from plants: antibacterial activity of plant volatile oils. Journal of Applied Microbiology, 88(2):308-316.

Dorman, H.J. and Deans, S.G. (2003) Antimicrobial agents from plants: antibacterial actvity plant volatile oils. Journal of Applied Microbiology, 88 (2): 308-316.

Erkan, N.; Ayranci, G. and Ayranci, E. (2008) Antioxidant activities of rosemary (Rosmarinus officinalis L.). Extract, blackseed (Nigella sativa L.) essential oil, carnosic acid, rosmarinic acid and sesamol. Food Chemistry, 110 (1): 76-82.

Gachkar, L .; Yadegari, D.; Rezaei, M.B.; Taghizadeh, M.; Astaneh ,S.D.A. and Rasooli, I. (2007) Chemical and biological characteristics of Cuminum cyminum and Rosmarinus officinalis essential oils. Food Chemistry,102 (3): 898904.

Glick, B. R.; Todorovic , B.; Czarny, J ; Cheng, Z .; Duan ,J . and McConkey , B. (2007) Promotion of Plant Growth by Bacterial ACC Deaminase, Critical Reviews in Plant Sciences, 26(5-6): 227-242.

Guesmi, A. and Boudabous, A. (2006) Activité antimicrobienne de cinq huiles essentielles associées dans les produits de thalassothérapie. Revue des Régions Arides, Numéro spécial : 224-230.

Hayouni, E.A.; Abedrabba, M.;Bouix, M. and Hamdi, M. (2007) The effects of solvents and extraction method on the phenolic contents and biological activities in vitro of Tunisian Quercus coccifera L. and Juniperus phoenicea L. fruit extracts. Food Chemistry,105 (3):1126-1134.

Hilan, C.; Sfeir ,R.; Jawish ,D . and Aitour, S . (2006) Huiles essentielles de certaines plantes médicinales libanaises de la famille des Lamiaceae . Lebanese Science Journal, 7 (2):13 -22.

Hosny , M.R.; El-Bastawesy ,A. M.; Abdel-Monem ,M. G.; Noor ,M.A ; Al-Mehdar , H .A. R.; Sharawy ,S .M. and El-Merzabani ,M. M .(2011) Antioxidant and anticarcinogenic effects of methanolic extract and volatile oil of fennel seeds (Foeniculum vulgare) .Journal of Medical Food,14 (9):986-1001.

Hussain ,A .I ; Anwar ,F .; Chatha ,S .A. S .; Jabbar , A .; Mahboob ,S .and Singh ,N. P. (2010) Rosmarinus officinalis essential oil: antiproliferative, antioxidant and antibacterial activities Brazilian Journal of Microbiology, .41(4): 1070-1078.

Karimi -Abdolrezaee, S.; Eftekhar , E; Jian ,W.; Cindi ,M .M. and Michael, G. F .(2006) Delayed Transplantation of Adult Neural Precursor Cells Promotes Remyelination and Functional Neurological Recovery after Spinal Cord Injury .The Journal of Neuroscience, 26(13):3377-3389.

Levy,L. (1969) Carrageenan paw edema in the mouse. Life Sciences, 8(11):601-606.

Manunta, A.1985. Influences of the $\mathrm{pH}$ of the substratum on the composition of the essential oil of Rosmarinus officinalis L. Studi sassaresi sez. 111 XXXII (86): 111-118.

Ponce, A.G.; Fritz, R.; Del Valle,C. and Roura, S.I. (2003) Antimicrobial activity of essential oils on the native microflora of organic Swiss chard. LWT. Food Science and Technology, 36 (7):679-684.

Rasooli, I.; Fakoor, M.H.; Yadegarinia, D.;Gachkar, L.; Allameh, A. and Rezaei, M.B. (2008). Antimycotoxigenic characteristics of Rosmarinus officinalis and Trachyspermum Copticum L. 
essential oils. International

Journal of Food Microbiology, 122(1-2):135-9.

Stefanovits-Bányai , É .; Tulok ,M. H.;

Hegedûs ,A.; Renner ,C. and

Szöllôsi Varga , I. (2003)

Antioxidant effect of various rosemary (Rosmarinus officinalis L.) clones $^{+}$. Acta Biologica Szegediensis, 47 (1-4):111-113.

Takano-Ishikawa Y.; Goto, $\mathrm{M}$ and

Yamaki, K. (2006) Structure activity relations of inhibitory effects of various flavonoides on liposachride included Praglandin E2 production in rat peritoneal macrophages:comparison between subclasses of flavonoides. Phytomedecine, 13(5): 310-317.

Wu,T .; Malinverni , J.; Ruiz, N.; Kim ,S.; Silhavy ,T. J. and Kahne ,D. (2005) Identification of a multicomponent complex required for outer membrane biogenesis in Escherichia coli .Cell, 121(2): 235-245. 